\title{
COORDINATION MOTOR ABILITIES AND SOMATIC GROWTH OF CHILDREN AND ADOLESCENTS WITH HEARING IMPAIRMENTS
}

\author{
Anna Zwierzchowska ${ }^{1}$; Aleksandra Żebrowska ${ }^{1}$; \\ Krystyna Gawlik ${ }^{2}$; Wojciech Smółka ${ }^{3}$; Bartosz Molik ${ }^{4}$; \\ Miguel Angel Gomez ${ }^{5}$; José A. Navia ${ }^{5}$
}

1. Institute of Sport Sciences The Jerzy Kukuczka Academy of Physical Education in Katowice, Poland.

2. Physiotherapy Department, The Pope John Paul II State School of Higher Education in Biala Podlaska, Poland.

3. Clinical Department of ENT. Medical University of Silesia, Poland.

4. Faculty of Rehabilitation. The Józef Pilsudski University of Physical Education, Poland.

5. Faculty of Physical Activity and Sport Sciences. Polytechnic University of Madrid, Spain.

\begin{abstract}
It is known that the development and maintenance of posture control are a prerequisite for qualified movement (motor adaptation, differentiation of movements, orientation). They are therefore necessary for the development of motor skills. The aim of the study was to evaluate the effect of selected factors differentiating human development on the level of coordination abilities of children and adolescents with hearing impairments. It was hypothesize that proportions, composition and body mass influence on the coordination motor abilities of children and adolescents with hearing impairment. A semi-longitudinal method was used and the study was conducted in three groups of participants aged 10,13 and 16 years three times in consecutive three years (at one-year intervals). The examinations were repeated each time for the same participants. Consequently, the study examined 56 participants aged between 10 and 18 years. Data from the study were obtained through direct observation, questionnaires, analysis of medical and pedagogical records as well as measurements of somatic growth ingredients and coordination of motor abilities. Analysis of somatic parameters revealed a progressive trend typical for this period of ontogeny in girls and boys. The body height and mass of the body, especially the increments of these parameters, will undoubtedly affect the motor coordination (changes in body proportions), while the fat mass, lean mass and overweight will strongly affect physical fitness. We observed statistical significance between parameters of somatic and plate tapping $(F 2,153=14.87 ; p<0.001)$, flamingo balance $\left(\mathrm{F}_{2,153}=9.23 ; \mathrm{p}<0.001\right)$ and march to the goal $\left(\mathrm{F}_{2,153}=8.49 ; \mathrm{p}<0.001\right)$, standing broad jump $\left(\mathrm{F}_{2,153}=8.10 ; \mathrm{p}<0.001\right)$, and catch of the Dietrich's stick $\left(\mathrm{F}_{2,153}=17.28 ; \mathrm{p}<0.001\right)$ for increments in the next years of observation specially. Statistically significant correlations between somatic parameters and motor coordination observed in our study participants confirm the importance of motor development for somatic potential and vice versa.
\end{abstract}

Keywords: motor adjustment, movement differentiation, orientation, somatic growth, deaf children

\section{COORDINACION DE HABILIDADES MOTORAS Y CRECIMIENTO SOMATICO DE NIÑOS Y ADOLESCENTES CON DISCAPACIDAD AUDITIVA}

\footnotetext{
RESUMEN

Se sabe que el desarrollo y el mantenimiento del control de la postura son requisitos previos para el movimiento de calidad (complejo) (adaptación motora, diferenciación de movimientos, orientación). Por lo tanto, son necesarios para el desarrollo de las habilidades motoras. El objetivo del estudio fue evaluar el efecto de determinados factores que diferencian el desarrollo humano a nivel de habilidades de coordinación de niños y adolescentes con discapacidad auditiva. Se planteó la hipótesis de que las proporciones, la composición y la masa corporal influyen en las habilidades motoras de coordinación de niños y adolescentes con discapacidad auditiva. Se utilizó un método
} 
semi-longitudinal y el estudio se realizó en tres grupos de participantes de 10, 13 y 16 años, tres veces en tres años consecutivos (a intervalos de un año). Las evaluaciones se repitieron cada vez para los mismos participantes. En consecuencia, el estudio examinó a 56 participantes con edades comprendidas entre 10 y 18 años. Los datos del estudio se obtuvieron mediante observación directa, cuestionarios, análisis de registros médicos y pedagógicos, así como mediciones de componentes de crecimiento somático y coordinación de habilidades motoras. El análisis de los parámetros somáticos reveló una tendencia progresiva típica de este período de ontogenia en niñas y niños. Los incrementos en altura y masa corporal afectarán la coordinación motora (especialmente los cambios en la proporción corporal); mientras que la masa grasa, la masa magra y el sobrepeso afectarán fuertemente a la condición física. Se observan diferencias significativas en función de la edad entre los parámetros del test de golpeo en placa $\left(\mathrm{F}_{2,153}=14.87 ; \mathrm{p}<0.001\right)$, test de equilibrio $\left(\mathrm{F}_{2,153}=9.23 ; \mathrm{p}<0.001\right)$ y marcha hacia la meta $\left(\mathrm{F}_{2,153}=8.49 ; \mathrm{p}<0.001\right)$, salto horizontal desde parados $\left(F_{2,153}=8.10 ; p<0.001\right)$, y captura del palo de Dietrich $\left(F_{2,153}=17.28 ; p<0.001\right)$. Las correlaciones estadísticamente significativas entre los parámetros somáticos y la coordinación motora observadas en los participantes de nuestro estudio confirman la importancia del desarrollo motor para el potencial somático y viceversa.

Palabras clave: ajuste del motor, diferenciación de movimiento, orientación, crecimiento somático niños sordos

Correspondence:

Anna Zwierzchowska

a.zwierzchowska@awf.katowice.pl

Associate Professor at the Jerzy Kukuczka Academy of Physical Education in Katowice.

Head of Department of Adapted Physical Activity.

40-066 Katowice, Mikołowska, Street 72 A, Poland.

Submitted: 06/03/2020

Accepted: 01/06/2020 


\section{INTRODUCTION}

Normal function of the sensory organs is a prerequisite for physical, motor and intellectual development. Hence, impaired function of even one of the senses may disturb the harmony of the above mentioned developmental triad. Nevertheless, the human body has considerable potential for compensatory changes which help maintain homeostasis. It has been evidenced that damage to one sensory function is compensated for by the other senses (Merabet \& Pascual-Leone, 2010). Although internal compensation is inherent in the physiology of human development, it depends on the stages of biological development which are characterized by different rate and dynamics. Compensatory mechanisms developed in people, especially children, with hearing impairments, are highly individual and determined by the child's physical and intellectual potential. Hearing loss resulting from neurological disorders is frequently associated with impaired organization and processing of input from somatic sense receptors by the central nervous system. Consequently, other spheres of development, and especially motor development, may also be affected.

As early as in 1967, Boyd emphasized that congenital deafness adversely affected visual-motor control (Boyd, 1967). Similarly, Horak et al. (1988) investigated the effect of vestibular status on motor coordination. They found that sensory organization deficits were associated with deficits in the development of motor proficiency. However, the studies of Brunt, Layne, Cook \& Rowe (1984), Zody \& Gorman (1990), and Zwierzchowska, Gawlik \& Grabara (2004), revealed that children with hearing impairments performed better in tasks used to assess visual-motor coordination compared to their hearing peers. Savelsbergh, Netelenbos \& Whiting (1991) studied auditory perception and the control of spatially coordinated action of children with deafness and hearing children.

They emphasized that auditory stimulation directed and intensified visual orientation behaviour, and observed that the lack of auditory stimulation during development could lead to deficiencies in the coordination of actions such as catching (Geddes,1978). Nevertheless, the aetiology and type of deafness might differentially determine the performance on balance tasks (Martens, Butterfield \& Lehnhard,1996; Rine et al., 2000; Zwierzchowska, Gawlik \& Grabara 2008). Static and dynamic postural control might also be challenged in children with hearing impairments. The development and maintenance of postural control are known to be a prerequisite for the performance of skilled movement (motor adjustment, movement differentiation, orientation); hence, they are essential for motor skills development (Ellis \& Darby, 1993; Shumway-Cook \& Woollacott, 1995; Shumway-Cook \& McCollum, 1991. Literature reports indicate that somatic 
parameters do not significantly affect the development of coordination motor abilities in a healthy population (Ljach, 1990) and argue that motor coordination is highly dependent on genetics. However, the fact that coordination skills can be effectively improved by physical training seems to contradict this opinion (Shumway-Cook \& McCollum, 1991; Ellis \& Darby, 1993). Thus, it is difficult to draw ultimate conclusions regarding the strength and direction of motor coordination. In this context, it is very important to examine changes in physical development, especially in the sensitive period of growth in ontogenesis. Oja and Jürimäe (1999) suggested that somatic variables are not very strong determinants of the development of coordination motor abilities and we attempted to verify this thesis.

The aim of the study was to evaluate the effect of selected factors differentiating human development on the level of coordination motor abilities of children and adolescents with hearing impairments.

Considering the results of the previous studies, it was hypothesized that:

1. Body proportions, composition and body mass influence coordination motor abilities in children and adolescents with hearing impairments.

Gender, age and the diversity of physical development dynamics are significant factors for the level of coordination motor abilities in children and adolescents with hearing impairment.

\section{Method}

\section{Participants}

A group of 56 children and adolescents with hearing impairments participated in a semi-longitudinal study. All participants were divided into 3 age subgroups: children1 (Gr. 1 - up to the age of 10), children2 (Gr. 2 - up to the age of 13), and adolescents (Gr. 3 - up to the age of 16). The relations between somatic growth components and coordination motor abilities variables were analysed with respect to age and sex. All variables were measured on three occasions (with yearly intervals) in the same participants (Table 1). 
TABLE 1

Demographic information of boys and girls with hearing impairments by age group and year of measure.

\begin{tabular}{lccccccc}
\hline \hline & & \multicolumn{2}{c}{ Group 1 } & \multicolumn{2}{c}{ Group 2 } & \multicolumn{2}{c}{ Group 3 } \\
\cline { 3 - 8 } Measure & $\begin{array}{c}\text { Men } \\
(\mathrm{n}=10)\end{array}$ & $\begin{array}{c}\text { Women } \\
(\mathrm{n}=4)\end{array}$ & $\begin{array}{c}\text { Men } \\
(\mathrm{n}=14)\end{array}$ & $\begin{array}{c}\text { Women } \\
(\mathrm{n}=8)\end{array}$ & $\begin{array}{c}\text { Men } \\
(\mathrm{n}=10)\end{array}$ & $\begin{array}{c}\text { Women } \\
(\mathrm{n}=10)\end{array}$ \\
\hline AGE & $1^{\text {st }}$ & $10.3 \pm 0.3$ & $10.0 \pm 0.3$ & $12.9 \pm 0.6$ & $13.5 \pm 1.0$ & $16.4 \pm 0.2$ & $16.3 \pm 0.3$ \\
& $2^{\text {nd }}$ & $11.3 \pm 0.3$ & $10.9 \pm 0.4$ & $13.6 \pm 0.8$ & $14.5 \pm 1.0$ & $17.4 \pm 0.2$ & $17.3 \pm 0.3$ \\
& $3^{\text {rd }}$ & $12.3 \pm 0.3$ & $11.9 \pm 0.4$ & $14.8 \pm 0.6$ & $15.5 \pm 1.0$ & $18.4 \pm 0.2$ & $18.3 \pm 0.3$ \\
\hline BH & $1^{\text {st }}$ & $142.0 \pm 5.7$ & $133.8 \pm 10.9$ & $157.1 \pm 10.5$ & $157.7 \pm 3.3$ & $172.6 \pm 6.8$ & $159.8 \pm 5.6$ \\
& $2^{\text {nd }}$ & $148.7 \pm 5.9$ & $139.3 \pm 10.7$ & $164.5 \pm 9.1$ & $158.8 \pm 3.6$ & $173.3 \pm 6.6$ & $161.1 \pm 5.2$ \\
& $3^{\text {rd }}$ & $155.3 \pm 6.8$ & $145.5 \pm 11.1$ & $170.7 \pm 8.3$ & $161.3 \pm 6.5$ & $173.9 \pm 7.1$ & $162.0 \pm 5.2$ \\
\hline BM & $1^{\text {st }}$ & $37.5 \pm 10.2$ & $38.3 \pm 15.1$ & $45.4 \pm 10.9$ & $51.7 \pm 7.1$ & $61.1 \pm 14.2$ & $54.0 \pm 6.7$ \\
& $2^{\text {nd }}$ & $41.2 \pm 11.2$ & $40.5 \pm 14.5$ & $54.1 \pm 19.2$ & $52.4 \pm 7.0$ & $59.6 \pm 15.9$ & $53.1 \pm 7.0$ \\
& $3^{\text {rd }}$ & $46.0 \pm 11.9$ & $46.6 \pm 18.5$ & $59.0 \pm 18.0$ & $56.0 \pm 8.3$ & $63.1 \pm 14.0$ & $55.3 \pm 9.3$ \\
\hline BMI & $1^{\text {st }}$ & $18.4 \pm 3.8$ & $20.8 \pm 5.2$ & $18.3 \pm 2.9$ & $20.8 \pm 3.0$ & $20.6 \pm 5.4$ & $21.1 \pm 2.4$ \\
& $2^{\text {nd }}$ & $19.0 \pm 3.6$ & $20.5 \pm 5.2$ & $19.6 \pm 5.3$ & $20.8 \pm 2.4$ & $19.9 \pm 5.7$ & $20.5 \pm 2.8$ \\
& $3^{\text {rd }}$ & $19.1 \pm 3.7$ & $21.5 \pm 6.2$ & $20.3 \pm 6.1$ & $21.9 \pm 3.0$ & $21.0 \pm 5.1$ & $21.5 \pm 3.3$ \\
\hline \multirow{2}{*}{ FAT } & $1^{\text {st }}$ & $18.9 \pm 9.8$ & $24.2 \pm 17.9$ & $14.6 \pm 8.2$ & $22.9 \pm 6.5$ & $11.1 \pm 8.0$ & $26.5 \pm 4.7$ \\
& $2^{\text {nd }}$ & $17.5 \pm 8.4$ & $19.6 \pm 15.2$ & $10.9 \pm 7.6$ & $22.9 \pm 7.0$ & $7.5 \pm 9.1$ & $19.6 \pm 7.3$ \\
& $3^{\text {rd }}$ & $14.7 \pm 9.7$ & $23.1 \pm 19.1$ & $10.1 \pm 8.4$ & $24.9 \pm 4.0$ & $10.2 \pm 6.4$ & $21.7 \pm 6.7$ \\
\hline FFM & $1^{\text {st }}$ & $29.1 \pm 5.0$ & $27.1 \pm 5.3$ & $39.3 \pm 7.0$ & $39.7 \pm 5.2$ & $53.4 \pm 6.8$ & $39.4 \pm 3.2$ \\
& $2^{\text {nd }}$ & $33.1 \pm 5.7$ & $31.0 \pm 7.8$ & $48.0 \pm 13.0$ & $40.4 \pm 4.7$ & $54.7 \pm 8.9$ & $42.6 \pm 2.7$ \\
& $3^{\text {rd }}$ & $28.8 \pm 12.8$ & $33.5 \pm 6.3$ & $50.6 \pm 9.8$ & $41.9 \pm 4.6$ & $55.9 \pm 8.0$ & $43.2 \pm 4.5$ \\
\hline \hline
\end{tabular}

Note $=$ Body height $(B H)[\mathrm{cm}]$, body mass $-(B M)[\mathrm{kg}]$, body mass index $-B M I,[\mathrm{~kg} / \mathrm{m} 2]$, percentage of fat tissue in body mass - FAT [\%] and fat free mass - FFM [\%].

All participants were students of schools for children with hearing impairments, and they had no intellectual disabilities or motor organ dysfunctions. Purposive sampling was used, based on the criteria of contemporary audiology (Parving, 1985). The selection criteria included severe hearing impairments diagnosed before the age of 3 (prelingual deafness) and established causation. All cases of undefined aetiology were excluded.

All participants with hearing impairments had hearing loss ranging from $80 \mathrm{~dB}$ and The group included $26.9 \%$ individuals with acquired hearing loss (e.g. resulting from meningitis before the age of 2), $17.7 \%$ with hereditary and $55.4 \%$ with congenital hearing loss (e.g. idiopathic).

\section{Procedure}

The study data were obtained by means of direct observation, questionnaires, analysis of medical and pedagogical records and measurements 
of somatic growth components and coordination motor abilities. Measurements included body height ( $\mathrm{BH}[\mathrm{cm}])$. For the measurement of body height, a wallmounted stadiometer with standard scales was used, with the accuracy of 0.5 $\mathrm{cm}$. Body mass [kg] was determined using a stand-on bioimpedance analyzer (BIA) Tanita BC 420SMA (Tanita Corporation, Japan). The study was performed according to a standard protocol recommended by the manufacturer: in the fasted state, in light clothing, without shoes and socks, with clean feet. The participants were instructed not to eat at least 2 hours before the measurement. The Analyzer samples periods of 5-second resistance values (Rx) and the reactance of their volume (Xc). This is the basis for calculating body composition by a computer program relative to age, sex and body height. Body height was also used to estimate body fat percentage. BMI was calculated by using the formula: BMI = body mass [kg]/body height [m²] ( Kyle et al., 2004).

Coordination motor abilities were evaluated with two of the Eurofit Physical Fitness Test Battery tests for children and youth aged 6-18 (tests 1,2). Apart from the Eurofit tests, four additional tests were used to evaluate other specific coordination abilities (Raczek, Juras \& Waśkiewicz 2001). All 6 tests were coordination tests: 1 . Plate tapping (speed of limb movement) - PT; 2. Flamingo balance (general balance) - FB; 3. Target jumping (kinesthetic differentiation) - TJ; 4. March to the goal (spatial orientation) -MG; 5. Standing broad jump forwards and backwards (movement adjustment and movement combination) - SBJ; 6. Catch of the Dietrich's stick (speed of reaction) - CDS. (Appendix 1.)

Each child with hearing impairment received a clear instruction and details of the experimental procedures from their regular school teacher in a sign language; the experiment was completed on the same day it was commenced. Anthropometric measurements were taken in a separate room. The tests of coordination motor abilities were performed in the afternoon in the school gymnasium.

The study of children and adolescents with hearing impairments was approved and authorized by the Bioethical Committee of the Academy of Physical Education. Additionally, legal guardians of the participants were provided with comprehensive information on the methods applied during the experiment and gave their written consent for their children to participate in the study.

\section{Statistical analysis}

Three different statistical analyses were performed to analyse the data. Firstly, the mixed linear model was used to analyse the longitudinal repeatedmeasures data from unbalanced samples (Cnaan, Laird \& Slasor, 1997). The present data include an unbalanced distribution (age group, year and sex), 
whereas the mixed linear model allows for the control of fixed and random effects with unbalanced designs that include missing data from any participant. The models included year, group age and sex as fixed effects and individual participant performance of each year as random effects (Hopkins, 2006). In order to control significant effects for fixed factors, the Bonferroni's post hoc test was applied to examine the pairwise comparisons of each significant factor, with the significance level set at $p<0.05$. Secondly, effects sizes (ES) were calculated to show the magnitude of the effects (standardized differences in means: Cohen's units) and their interpretation was based on the following criteria: $<0.2=$ trivial, 0.2 to $0.6=$ small effect, 0.6 to $1.2=$ moderate effect, 1.2 to $2.0=$ large effect, and $>2.0=$ very large (Cnaan et al. 1997). The effect sizes values were presented as $90 \%$ confidence interval (CI). Thirdly, interrelations between somatic and motor ability parameters as well as changes in their increments in each year studied were verified by means of the Spearman's correlation analysis. The statistical analyses were performed using IBM SPSS statistics for Windows, version 20.0 (Armonk, NY: IBM. Corp.).

\section{RESULTS}

Firstly, the results from the mixed linear model showed that age group was statistically significant between groups for plate tapping $\left(F_{2,153}=6.87 ; p<0.001\right)$, standing broad jump $\left(\mathrm{F}_{2,153}=4.70 ; \mathrm{p}=0.010\right)$, and catch of the Dietrich's stick $\left(F_{2,153}=8.85 ; p<0.001\right)$. The sex fixed factor showed significant differences by sex plate tapping $\left(\mathrm{F}_{1,153}=22.20 ; \mathrm{p}<0.001\right)$, target jumping $\left(\mathrm{F}_{1,153}=9.36\right.$; $\mathrm{p}=0.003)$, standing broad jump $\left(\mathrm{F}_{1,153}=22.86 ; \mathrm{p}<0.001\right)$, and catch of the Dietrich's stick $\left(\mathrm{F}_{1,153}=10.81 ; \mathrm{p}<0.001\right)$. Finally, the year of the study was significant for plate tapping $\left(\mathrm{F}_{2,153}=14.87 ; \mathrm{p}<0.001\right)$, Flamingo balance $\left(\mathrm{F}_{2,153}=\right.$ 9.23; $\mathrm{p}<0.001)$, march to the goal $\left(\mathrm{F}_{2,153}=8.49 ; \mathrm{p}<0.001\right)$, standing broad jump $\left(F_{2,153}=8.10 ; p<0.001\right)$, and catch of the Dietrich's stick $\left(F_{2,153}=17.28 ; p<0.001\right)$. Specifically, the pairwise comparisons were presented in figure 1 including the magnitudes (effect sizes and 90\% IC) showed that year 2 compared with year 1 was large or very large for plate tapping and flamingo balance tests with negative and positive values, respectively. Also, there were moderate values for march to the goal (positive values), standing broad jump (negative values), and catch of the Dietrich's stick (negative values). The year 3 comparisons with year 1 showed very large effects for plate tapping (negative values), large effects for Catch of the Dietrich's stick (negative values) and moderate effects for flamingo balance, march to the goal, and standing broad jump (positive values). The comparisons between year 3 and year 2 showed moderate values for plate tapping (negative values), catch of the Dietrich's stick (negative values), flamingo balance (positive values) and standing broad jump (negative values). 


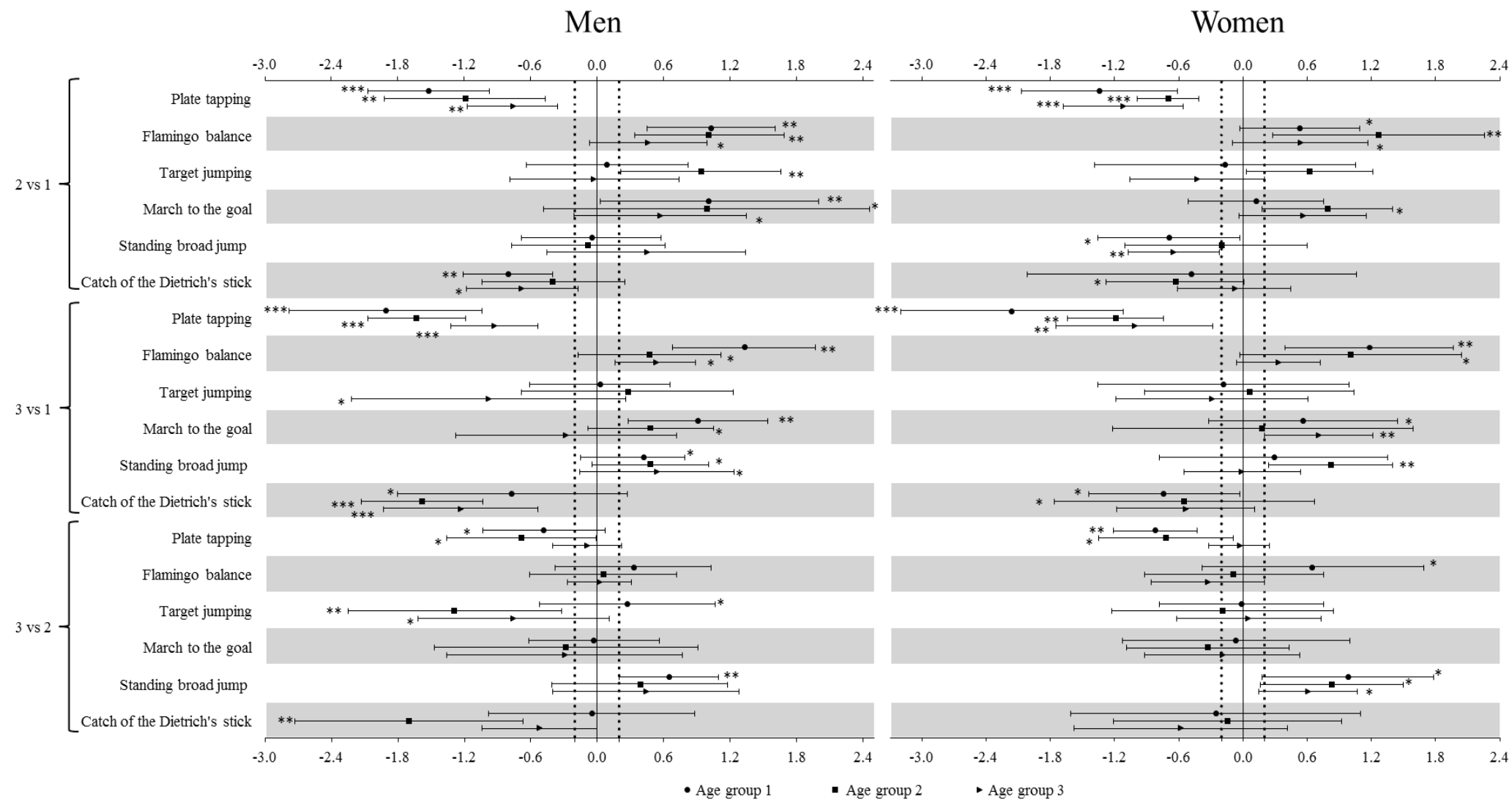

FIGURE 1: Effect sizes (90\% IC) of differences in means of each test of individual participants according to year comparisons ( 2 vs 1,3 vs 1 , and 3 vs 2 ) for each sex (men and women) and age group (1,2 and 3). Asterisks indicate the magnitude of the effect size as follows: ${ }^{*}$ modera te; ${ }^{* *}$ large; ${ }^{* *}$ very large. Asterisks located in the trivial area (dotted line) denote trivial effects 
The age group comparisons showed differences for plate tapping between group 1 and 2 (ES= 2.71 [2.07-3.35], very large), groups 1 and 3 (ES= 1.53 [1.17-1.89], large), and groups 3 and 2 (ES=0.80 [0.23-1.37], moderate), for standing broad jump between groups 1 and 2 (ES=0.47 [0.20-1.14], small), groups 1 and 3 (ES= -0.17 [-0.29-0.63], small), and groups 3 and 2 (ES= 0.57 [0.07-1.20], small), and for catch of the Dietrich's stick between groups 1 and 2 ( $E S=1.43$ [0.83-2.02], large), groups 1 and 3 (ES= 0.96 [0.45-1.47], moderate), and groups 3 and 2 (ES=0.42 [0.16-1.0], small). Finally, the differences by sex showed positive values for men compared with women in plate tapping (ES= 0.51 [0.16-0.86], small), target jumping (ES=0.37 [-0.09-0.83], small), and catch of the Dietrich's stick (ES=0.71 [0.32-1.11], moderate), but negative values in standing broad jump (ES= -0.22 [-0.61-0.17], small).

Secondly, the results of Spearman's correlations are presented in table 2. The first measurement results showed that for the females' age group 1 the plate tapping and catch of the Dietrich's stick were significantly correlated with body mass, the flamingo balance and march to the goal with \%FFM, and the catch of the Dietrich's stick with the body height. The females' age group 2 obtained significant correlations between plate tapping and \%FFM and between flamingo balance and body height. The females' age group 3 only showed significant correlations between standing broad jump and BMI and \%FAT. On the other hand, the males' age group 1 showed significant correlations between standing broad jump and body height, BMI, \%FAT, and \%FFM. The age group 2 showed significant correlations between plate tapping and BMI and \%FAT, and between target jumping and \%FAT. The males' age group 3 showed no significant correlations between somatic parameters and coordination motor abilities.

The results of the first year increments for females showed significant correlations of flamingo balance and standing broad jump with the \%FAT in the age groups 1 and 3 , respectively. The age group 2 showed no significant correlations. The results for male students showed significant correlations between plate tapping and body height and the catch of the Dietrich's stick with BMI in age group 1, between standing broad jump and body height and \%FFM in age group 2, and between plate tapping with \%FAT and standing broad jump with body mass, BMI and \%FFM.

Finally, the results of the second year increments for females showed significant correlations between target jumping and \%FAT and between plate tapping and BMI in the age group1, between plate tapping and \%FFM and body height in the age groups 2 and 3, respectively. The results for males showed significant correlations between target jumping and body height in the age group 1, between march to the goal and \%FFM in the age group 2, and between 
flamingo balance, body mass, BMI, and \%FAT and between plate tapping and body height, body mass, BMI, \%FAT, and \%FFM in the age group 3.

TABLE 2

Spearman correlation matrix (and p value) between increments in somatic components, indices and coordination motor abilities in women and men with hearing impairments.

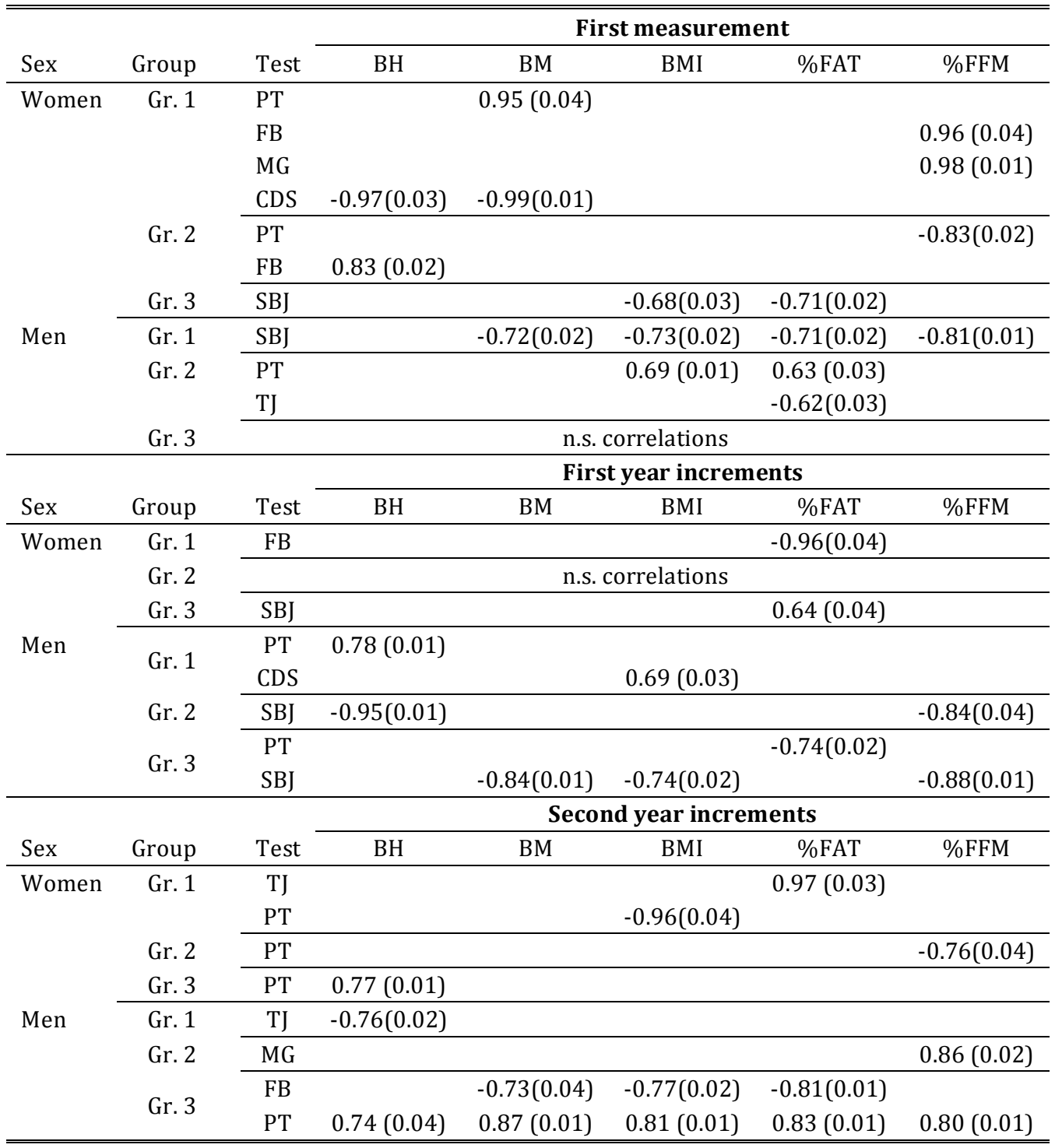

Note $=$ Body height $(\mathrm{BH})[\mathrm{cm}]$, body mass - (BM) [kg], body mass index $-B M I,[\mathrm{~kg} / \mathrm{m} 2]$, plate tapping - PT; flamingo balance - FB; target jumping - TJ; march to the goal - MG; standing broad jump - SBJ; and catch of the Dietrinch's stick - CDS. 


\section{DISCUSSION}

It has been demonstrated empirically that the development of coordination skills in individuals with hearing impairments is quite specific and divergent compared to those who have normal hearing thresholds (Zwierzchowska et al 2008). Motor coordination requires high efficiency of both movement apparatus and the nervous system which is not always the case in people with hearing impairments. The body itself frequently compensates for hearing loss via cross-modal plasticity (Cybulska-Kłosowicz \& Kossut, 2006), which can strengthen other sensory systems to compensate for the lack of hearing or vision. Experiments carried out in recent years have demonstrated that brain areas suffering sensory deprivation can become activated through higher-level cognitive functions such as language processing. In the auditory deprived brain, processing of visual stimuli evokes activity in the temporal auditory cortex and occipital cortex (Amedi, Raz, Pianka, Malach, Zohary, 2003; Amedi, Floel, Knecht, Zohary, Cohen, 2004; Roeder, Stock, Bien, Neville, Rosler, 2002). Hence, individuals with hearing impairments exhibit shorter reaction time to visual stimuli compared to their hearing counterparts, and especially when the visual stimulus appears in the peripheral visual field (Bottari, Caclin, Giard \& Pavani, 2011; Hauthal, Sandmann, Debener \& Thorne, 2013). These data seem to confirm the hypothesis that people with hearing impairments compensate for hearing loss through the development of extreme efficiency of another sense organ. However, researchers are not unanimous in this respect; some claim that deprivation of even one form of sensory input has a negative impact on the function of the remaining sense organs (Horak et al., 1988; Rine et al., 2000; Quittner, Smith, Osberger, Mitchell \& Katz, 1994):, Zwierzchowska et al., 2008), which would undoubtedly deepen delays in physical development. Our findings are closer to the hypothesis of sensory compensations since it was demonstrated that both reaction speed and hand movement speed were significantly correlated with age of the participants. Furthermore, the results were significantly better with every year of observation and for each age group. This effect is consistent with the physiological model of human development.

The findings of our studies on populations with hearing impairments seem quite consistent with those of Oja \& Jürimäe (1999), who suggested that somatic variables are not very strong determinants of the development of coordination motor abilities. It has been demonstrated that the variability of somatic parameters might positively affect motor coordination. Our study revealed correlations between somatic components and several coordination motor abilities. The strength of the majority of these correlations ranged from 0.7 to 0.9 , suggesting moderate and strong correlations. Fat mass, body height, and mass as well as BMI correlated significantly with coordination motor abilities (the higher the value of a somatic variable, the lower motor adjustment, 
spatial orientation, speed of reaction and kinaesthetic differentiation). These correlations were positive and more frequently observed in girls. It might be concluded that age-appropriate body-build (body height and mass) has an impact on age-related changes in coordination motor abilities girls. Statistically significant correlations between somatic parameters and motor coordination observed in our study participants confirm the importance of motor development for the somatic potential and vice versa. Body height and mass, and especially increments in these parameters, will undoubtedly affect motor coordination (changes in body proportions) whereas fat mass, fat free mass and BMI will strongly influence physical fitness. This thesis is consistent with the previous findings (Ellis \& Derby 1993; Zwierzchowska 2013; Zwierzchowska \& Bieńkowska, 2017).

The formation of a favourable attitude of the child towards his/her physique may indirectly affect the level of motor skills. Thus, the above described phenomena are not universal. Instead, differences in the development of some coordination motor abilties should be emphasized, especially those skills which depend on visual input. According to Qittner et al., (1992), Savelsbergh, Netelenbos \& Whiting, (1991) and Willems \& Hagot, (2007) dynamic visualization, which is characteristic of early childhood of people with hearing impairments, might compensate for auditory deficits. The problem was not analyzed in this respect. However, this seems to be an interesting direction for further research on the effect of hearing on the development of coordination abilities, especially when visual perception is a dominant compensatory sense. However, it can be supposed that even though coordination motor abilities in children with hearing impairments develop in the presence of sensorineural deficits, this exhibits compensatory resources in the form of regulatory and cognitive processes which also influence the development of these abilities.

\section{Conclusions}

It can be concluded that the correlations of somatic characteristics and their increments with coordination motor skills and their variability represent the strength of human development that can be used in the process of rehabilitation of patients with hearing impairments. Instilling proper attitudes of children towards their own physical health may have an indirect positive effect on the level of their motor skills, which seems to be especially important in rehabilitation and compensation of sensorimotor deficits in children with hearing impairments. The study demonstrated that time and sex factors are substantial determinants of the level of coordination motor abilities. 


\section{REFERENCES}

Amedi A, Raz N, Pianka P, Malach R, Zohary E. (2003). Early 'visual' cortex activation correlates with superior verbal memory performance in the blind. Nature Neuroscience, 6, 758-766.

Amedi A., Floel A., Knecht S., Zohary E., Cohen L. G. (2004). Transcranial magnetic stimulation of the occipital pole interferes with verbal processing in blind subjects. Nature Neuroscience. 7, 1266- 1270.

Bottari, D., Caclin, A., Giard, M. H., Pavani, F. (2011). Changes in early cortical visual processing predict enhanced reactivity in deaf individuals. PloS one, 6(9), e25607. https://doi.org/10.1371/journal.pone.0025607;

Boyd J. (1967): Comparasion of motor behaviour in deaf and hearing boys. American Annals of the Deaf, 112, 598-605

Brunt D., Layne C.S., Cook M., Rowe L. (1984). Automatic postural responses of deaf children from dynamic and static positions. Adapted physical activity quarterly, 1, 247- 252.

Cnaan A, Laird NM, Slasor P. (1997). Using the general linear mixed model to analyse unbalanced repeated measures and longitudinal data. Statistics in Medicine, 16, 2349-2380.

Cybulska-Kłosowicz A., Kossut M. (2006). Interhemispheric interaction in brain plasticity. Neuropsychiatria i Neuropsychologia, 1(1), 15-23.

Ellis M.K., Darby L.A. (1993). The effect of balance on the determination of peak oxygen consumption for hearing and non hearing female athletes. Adapted physical activity quarterly, 10(3), 216-225

Geddes, D. (1978): Motor development profiles of preschool deaf and hard-ofhearing children. Perceptual and Motor Skills, 46, 291-294.

Hauthal, N., Sandmann, P., Debener, S., \& Thorne, J. D. (2013). Visual movement perception in deaf and hearing individuals. Advances in Cognitive Psychology, 9(2), 53-61.

Hopkins WG. (2006). Spreadsheet for analysis of controlled trials with adjustment for a subject characteristics. Sport Science, 10, 46-50.

Horak FB., Shumway-Cook A., Crowe TK., Black FO. (1988). Vestibular function and motor proficiency of children with impaired hearing, or with learning disability and motor impairment. Developmental Medicine \& Child Neurology, 30, 64-79.

Kyle UG, Bosaeus I, De Lorenzo AD, Deurenberg P, Elia M, Manuel Gomez J, et al. Bioelectrical impedance analysis part II: utilization in clinical practice. Clinical Nutrition, 23, 1430-53.

Ljach W.I. (1990). Senzitiwnyje periody razwitja koordinacjonnych sposobnostiej dietiej w szkolnom wozrastje. Teorija I Praktika Fiziczeskoj Kultury, 3, 14-24. 
Martens D., Butterfield SA., Lehnhard RA. (1996). A kinematic analysis of static balance task by children who are deaf. Clinical Kinesiology, 49, 106-110.

Merabet, L. B., \& Pascual-Leone, A. (2010). Neural reorganization following sensory loss: the opportunity of change. Nature Reviews Neurosciences, 11(1), 44-52.

Oja, L. and Jürimäe, T.(1999). The influence of somatic development to the motor ability and fundamental motor skill performance in 6-year-old children, in Sport Kinetics '97, Blaser, P., Ed., Czwalina Verlag, Hamburg, 1999, 168.

Parving A. (1985). Hearing disorders in children, some procedures for detection, identification, and diagnostic evaluation. International Journal of Pediatric Otorhinolaryngology, 9 (1) 31-57.

Quittner A. L., Smith L.B., Osberger M. J., Mitchell T.V., Katz D. B. (1994): The impact of audition on the development of visual attention. Psychological Science, 5(6), 347-353.

Raczek J., Juras G., Waśkiewicz Z. (2001). The diagnosis of motor coordination. Journal of Human Kinetics, 6, 113-125.

Rine RM., Cornwall G. Gan K., Locasicio C., O‘Hare T., Robinson, Rice M. (2000). Evidence of progressive delay of motor development in children with sensorineural hearing loss and concurrent vestibular dysfunction. Perceptual and Motor Skills , 90 (2\2): 1101- 1112.

Roeder B., Stock O., Bien S., Neville H., Rosler F. (2002). Speech processing activates visual cortex in congenitally blind humans. The European Journal of Neuroscience, 16, 930-936.

Savelsbergh GJ, Netelenbos JB., Whiting HT. (1991). Auditory perception and the control of spatially coordinated action of deaf and hearing children. Journal of Child Psychology and Psychiatry, 32 (3): 489-500.

Shumway-Cook A, Woollacott MH. (1995). Motor Control: Theory and Practical Applications. Baltimore, Md: Williams \& Wilkins.

Shumway-Cook A., McCollum G. (1991) Assessment and treatment of balance deficits. Edited by Montgomery P.C., Connolly B.H., Motor Control and Physical Therapy: Theoretical Framework and Practical Applications. Hixson, Tenn: Chattanooga Group Inc., 123-137.

Willems R. M. Hagoort, P.( 2007). Neural evidence for the interplay between language, gesture, and action: a review. Brain and Language, 101, 287-98.

Zody J.M., Gorman D.R. (1990). Factorial study of manipulative tests administered to children with deafness ages eight to fifteen. Journal of Human Movement Studies, 2, 85-91.

Zwierzchowska A. (2013). Morphological variability and functional development of deaf children and adolescents (Zmienność morfologiczna a rozwój funkcjonalny dzieci i młodzieży niesłyszącej). Katowice: AWF. 
Zwierzchowska A, Bieńkowska KI. The significance of the physical and motor potential for speech development in children with cochlear implant (CI) preliminary study. Logopedia, 46, 91-105.

Zwierzchowska A., Gawlik K., Grabara M. (2004). Energetic and coordination abilities of deaf children. Journal of Human Kinetics, 11, 83-92.

Zwierzchowska A., Gawlik K., Grabara M. (2008). Deafness and motor abilities level. Biology of Sport, 25(3): 263-274.

\section{APPENDIX: TESTS USED TO ASSESS COORDINATION MOTOR ABILITIES}

1. Flamingo balance (general balance)

Factor: static balance of the whole body; dimension: balance. Test description: With hands placed on the hips, the tested person performs a heel raise with eyes closed. Time of maintaining balance. Result recorded: the better result of two attempts.

\section{Plate tapping}

Factor: the speed of movements of the upper limbs; dimension: speed. Test description: Tap quickly two adequately spaced disks, alternately with a chosen (dominant) hand. Result recorded: the better result of two attempts. The result is determined by the time needed to tap each disc 25 times, measured with the accuracy of $0.1 \mathrm{sec}$. If the tested person does not tap the disc, an additional movement is added to the required 25 cycles.

\section{Kinaesthetic differentiation}

Jump on the line (from box to the target). Equipment and aids: $90 \mathrm{~cm}$ vaulting box, 1 mattress, tape measure, blindfold. The player is standing on the box. On the mattress pushed close to the longer side of the box, a line parallel to its edge is drawn $1 \mathrm{~m}$ apart. The athlete visually assesses the distance to the line, and then with his or her eyes closed, attempts to jump from the box to the line as accurately as possible (attempts to hit the line with his or her heels). The distance from the heel line to the line on the mattress is measured. After the explanation and demonstration, five attempts are performed. Result recorded: the best of the five attempts is recorded after the rejection of the two extreme results.

\section{Spatial orientation}

Walking to the goal. Equipment: tape measure, blindfold. A circle with a diameter of $1 \mathrm{~m}$ is drawn at a distance of $5 \mathrm{~m}$ from the starting line, its centre is marked with a cross with a clearly visible coloured tape. The tested person, standing in front of the line, visually assesses the distance to the centre of the circle and then, wearing the blindfold, he or she is instructed to attempt to 
reach the centre of the circle slowly, stop and raise his hand. The distance from the point between the feet of the tested person to the centre of the circle is measured in centimetres. The test is performed three times and the mean result of the three tests is recorded.

\section{Target jumping (kinaesthetic differentiation)}

Forward and backward standing long jump The tested person makes three standing jumps forward to the maximum distance, then jumps back three times as far as he can. The best results in forward and backward jumps are used for calculations. Motor adjustment is expressed by the difference (in centimetres) between the results of forward and backward jumps. The smaller the difference, the higher the level of this ability.

\section{Speed of reaction}

Ditrich stick catching test. Accessories: stock, chair. The tested person sits down on the chair with his face facing the backrest, putting his forearm on it. The researcher, holding the stick by its upper end, sets the lower one with the lower edge of a vertically placed hand at a distance of $1 \mathrm{~cm}$ from its inner surface. After 2 to 4 seconds the researcher releases the grip of the stick and the athlete reacts to its movement by clenching his hand as soon as possible. The value of how many centimetres it fell down before clenching is read from the scale placed on the stick. 